\title{
Syndrome of inappropriate antidiuretic hormone secretion due to treatment of lung cancer with cisplatin
}

\author{
TJ LITTLEWOOD, A PETER SMITH
}

\author{
From the Department of Chest Medicine, Llandough Hospital, Penarth, South Glamorgan
}

Cisplatin (cisdichlorodiammineplatinum 11) is used increasingly in the chemotherapy of malignant tumours, including carcinoma of the bronchus. We report here two cases of dilutional hyponatraemia secondary to the inappropriate secretion of antidiuretic hormone that developed in two patients with bronchial carcinoma receiving treatment with cisplatin.

\section{Case reports}

CASE 1

A 61 year old woman presented with a two day history of pleuritic chest pain and a productive cough. Material obtained by biopsy of an endoscopically visible bronchial tumour showed appearances of small cell undifferentiated carcinoma. Staging procedures suggested that this was confined to the thorax. Haematological and biochemical indices were normal. She commenced treatment with two cycles of intravenous vincristine $1.2 \mathrm{mg} / \mathrm{m}^{2}$, adriamycin 40 $\mathrm{mg} / \mathrm{m}^{2}$, and cyclophosphamide $760 \mathrm{mg} / \mathrm{m}^{2}$, alternating with two cycles of intravenous cisplatin $100 \mathrm{mg} / \mathrm{m}^{2}$ and etoposide $110 \mathrm{mg} / \mathrm{m}^{2}$, at intervals of three weeks. Having completed the first two cycles uneventfully she was readmitted for her third cycle and before starting the cisplatin infusion underwent a period of prehydration with mannitol diuresis as described by Hayes et al 1977.' The results of electrolyte and osmolality determinations before and after treatment are detailed in the table. Before treatment her blood pressure was $150 / 90 \mathrm{~mm} \mathrm{Hg}$ and this did not alter appreciably during the period of fluid volume overload. The syndrome of inappropriate antidiuretic hormone secretion was diagnosed and fluid restriction was imposed, which resulted in the return of her serum electrolytes to normal within 10 days. Chemotherapy was subsequently continued without cisplatin and there were no further episodes of electrolyte disturbance during the course of her illness, although she failed to respond to chemotherapy and died six months after the onset of symptoms.

Address for reprint requests: Dr TJ Littlewood, Department of Haematology, Llandough Hospital, Penarth, S Glamorgan CF6 $1 \mathrm{XX}$.

Accepted 20 March 1984
CASE 2

A 62 year old man developed malaise, weight loss, cough, and hypertrophic pulmonary osteoarthropathy and was found to have an undifferentiated squamous cell carcinoma of the bronchus, confirmed by biopsy of an endoscopically visible bronchial lesion. As the tumour was inoperable he began treatment with cycles of cisplatin $100 \mathrm{mg} / \mathrm{m}^{2}$ and etoposide $110 \mathrm{mg} / \mathrm{m}^{2}$ given intravenously at three weekly intervals. Before and during each infusion of cisplatin a period of prehydration and mannitol diuresis was instituted.' He became increasingly drowsy after receiving the cisplatin infusion and within 24 hours of the start of the infusion had two grand mal convulsions. Although the plasma sodium concentration was normal before treatment, hyponatraemia was now noted and the syndrome of inappropriate antidiuretic hormone secretion was diagnosed on the basis of the urine and plasma osmolalities in the presence of normal renal function (table).

His blood pressure initially was $170 / 100 \mathrm{~mm} \mathrm{Hg}$ and he remained mildly hypertensive throughout the period of fluid volume overload. He responded completely to fluid restriction and cisplatin was withdrawn from his treatment protocol. He died six weeks later from carcinomatosis without further evidence of serum electrolyte disturbance.

\section{Discussion}

Cisplatin has many side effects but there has been only one report of the syndrome of inappropriate antidiuretic hormone secretion after cisplatin infusion. ${ }^{2}$ The syndrome has also been documented after treatment with vincristine ${ }^{3}$ and cyclophosphamide, ${ }^{4}$ and raised plasma concentrations of antidiuretic hormone associated with emesis induced by chemotherapys has been reported. Neither of our patients, however, had more than mild nausea and vomiting after treatment and, although the first patient had received treatment with vincristine and cyclophosphamide, the normal plasma electrolytes before cisplatin infusion make it unlikely that the former drugs were responsible for the syndrome of inappropriate antidiuretic hormone secretion in this case.

Cisplatin is known to be nephrotoxic but appreciable nephrotoxicity is not seen when a mannitol diuresis is induced concurrently ${ }^{6}$ and neither of our patients showed evidence of dehydration or oliguric renal failure. 
Plasma and urine osmolalities, with plasma sodium and urea concentrations, in relation to cisplatin infusion in the two cases

\begin{tabular}{|c|c|c|c|c|c|}
\hline \multirow[t]{2}{*}{ Day* } & \multicolumn{3}{|l|}{ Plasma } & \multicolumn{2}{|l|}{ Urine } \\
\hline & Sodium (mmol/l) & Urea (mmolll) & Osmolality (mmol/l) & Osmolality (mmol/l) & Volume (ml) \\
\hline $\begin{array}{c}\text { CASE 1 } \\
0 \\
1 \\
3 \\
5 \\
10 \\
\text { Fluid r }\end{array}$ & $\begin{array}{l}140 \\
128 \\
120 \\
125 \\
134 \\
600 \mathrm{~m} / \text { day was in }\end{array}$ & $\begin{array}{l}4 \cdot 6 \\
2 \cdot 8 \\
4 \cdot 1 \\
5 \cdot 3 \\
7 \cdot 3 \\
\text { tted from day } 1\end{array}$ & $\begin{array}{l}295 \\
265 \\
245 \\
265 \\
275 \\
10\end{array}$ & $\begin{array}{l}- \\
\overline{620} \\
640 \\
520\end{array}$ & $\begin{array}{l}3200 \\
2700 \\
2200 \\
1400\end{array}$ \\
\hline $\begin{array}{c}\text { CASE } 2 \\
-1 \\
1 \\
2 \\
3 \\
5 \\
10 \\
\text { Fluid re }\end{array}$ & $\begin{array}{l}140 \\
114 \\
122 \\
130 \\
134 \\
140 \\
500 \mathrm{ml} / \text { day was in }\end{array}$ & $\begin{array}{l}4 \cdot 8 \\
2 \cdot 3 \\
2 \cdot 9 \\
5 \cdot 3 \\
4 \cdot 8 \\
4 \cdot 4 \\
\text { ted from day } 1\end{array}$ & $\begin{array}{l}-\overline{235} \\
250 \\
270 \\
280 \\
295 \\
8 .\end{array}$ & $\begin{array}{l}- \\
680 \\
670 \\
620 \\
540 \\
-\end{array}$ & $\begin{array}{l}\overline{4240} \\
4120 \\
3210 \\
2460 \\
-\end{array}$ \\
\hline
\end{tabular}

*Day 0 = day of cisplatin infusion.

Conversion: SI to traditional units-Sodium: $1 \mathrm{mmol}=1 \mathrm{mEq}$; urea: $1 \mathrm{mmol}=6 \mathrm{mg} / 100 \mathrm{ml}$; osmolality: $1 \mathrm{mmol}=1 \mathrm{mosmol}$.

Adrenocortical function was assessed in the second case and was found to be normal, the cortisol concentration being $675 \mathrm{nmol} / \mathrm{l}$ in the early morning and $285 \mathrm{nmol} / \mathrm{l}$ at midnight (normal range $140-800 \mathrm{nmol} / \mathrm{l}$ ). Adrenocortical function, however, was not determined in the first case. As plasma antidiuretic hormone was not estimated it remains uncertain whether hyponatraemia after cisplatin infusion was due to central stimulation or to peripheral potentiation of antidiuretic hormone by cisplatin, or whether the tumours were responsible for subclinical inappropriate antidiuretic hormone secretion, which became clinically manifest during the phase of prehydration and forced diuresis. The frequency of the syndrome of inappropriate antidiuretic hormone secretion associated with small cell carcinoma of the bronchus is $9 \cdot 5-12 \% ;^{78}$ but the syndrome is much rarer in association with squamous cell carcinoma of the bronchus and this, coupled with the maximum reduction in plasma sodium $24-48$ hours after cisplatin infusion, makes the former mechanism much more likely. The syndrome of inappropriate antidiuretic hormone secretion secondary to cisplatin is clearly rare but as cisplatin is increasingly used in the treatment of malignant tumours it may become increasingly recognised.

We would like to thank Dr IA Campbell for permission to report on one of his patients.

\section{References}

' Hayes DM, Cvitkovic E, Golby RB, Scheiner E, Helson L, Krafoff IH. High dose cis platinum diammine dichloride. Amelioration of renal toxicity by mannitol diuresis. Cancer 1977;39: 1372-81.

${ }^{2}$ Levin L, Sealy R, Barron J. Syndrome of inappropriate antidiuretic hormone secretion following cis dichlorodiammineplatinum 11 in a patient with malignant thymoma. Cancer 1982;50:2279-82.

${ }^{3}$ Fine RN, Clark RR, Shore NA. Hyponatraemia and vincristine therapy. Syndrome possibly resulting from inappropriate antidiuretic hormone secretion. Am J Dis Child 1966;112:256-9.

4 Steele TH, Serpeck AA, Block JB. Antidiuretic hormone response to cyclophosphamide in man.J Pharmacol Exp Ther 1973;185:245-53.

${ }^{5}$ Fisher RD, Rentschler RE, Nelson JC, Godfrey TE, Wilbur DW. Elevation of plasma antidiuretic hormone (ADH) associated with chemotherapy-induced emesis in man. Cancer Treatment Reports 1982;66:25-9.

- Stark JJ, Howell SB. Nephrotoxicity of cisplatinum (11) dichlorodiammine. Clin Pharmacol Ther 1978;23:461-6.

' Lokich JJ. The frequency and clinical biology of the ectopic hormone syndromes of small cell carcinoma. Cancer 1982;50:2111-4.

${ }^{8}$ Comis RL, Miller M, Ginsberg SJ. Abnormalities in water homeostasis in small cell anaplastic lung cancer. Cancer 1980;45:2414-21. 